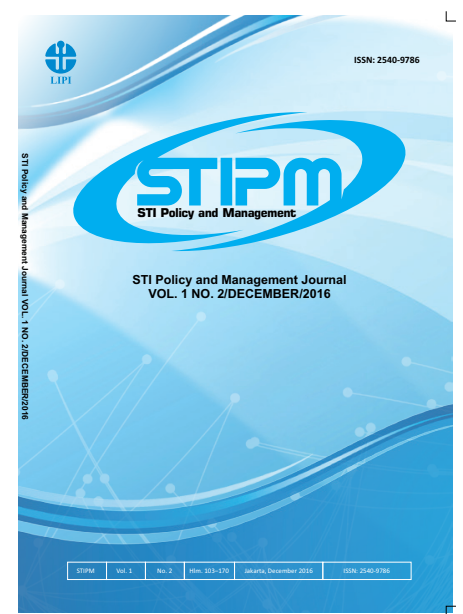

Journal of STI Policy and Management

Publication details, including instructions for authors and subscription information: http://www.stipmjournal.org/

\title{
Dynamics of Bioplastics Development in Indonesia
}

\section{Qinan Maulana B. Soesanto, Dian Prihadyanti, Hartiningsih, Trina Fizzanty}

Center for Science and Technology Development Studies, Indonesian

Institute of Sciences

Version of record first published: 15 December 2016

To cite this article: Soesanto, Q. M. B., Prihadyanti, D., Hartiningsih, Fizzanty, T. (2016). Dynamics of Bioplastics

Development in Indonesia. Journal of STI Policy and Management, 1(2), 153-161

To link to this article: http://dx.doi.org/10.14203/STIPM.2016.48

ISSN 2540-9786 (Print); ISSN 2502-5996 (online)

Accreditation Number: 622/AU3/P2MI-LIPI/03/2015

Full terms and conditions of use: https://creativecommons.org/licenses/by-nc-sa/4.0/

You are free to:

- Share : copy and redistribute the material in any medium or format

- Adapt : remix, transform, and build upon the material

- The licensor cannot revoke these freedoms as long as you follow the license terms.

Under the following terms:

Attribution - You must give appropriate credit, provide a link to the license, and indicate if changes were made. You may do so in any reasonable manner, but not in any way that suggests the licensor endorses you or your use.

NonCommercial - You may not use the material for commercial purposes.

ShareAlike - If you remix, transform, or build upon the material, you must distribute your contributions under the same license as the original.

No additional restrictions - You may not apply legal terms or technological measures that legally restrict others from doing anything the license permits.

Notices:

- You do not have to comply with the license for elements of the material in the public domain or where your use is permitted by an applicable exception or limitation.

- No warranties are given. The license may not give you all of the permissions necessary for your intended use. For example, other rights such as publicity, privacy, or moral rights may limit how you use the material.

- If you copy the dataset merely to extract the uncopyrightable data elements would not need permission to do so. However, if you republish the full dataset or using the copyrightable data layers require a permission from PAPPIPTEK-LIPI. 


\title{
SCIENCE, TECHNOLOGY AND INNOVATION POLICY AND MANAGEMENT (STIPM) JOURNAL Volume 01, Number 02, December 2016
}

\author{
FOREWORD by EDITOR-in-CHIEF
}

We are very pleased to present the second issue of the Science, Technology and Innovation Policy and Management (STIPM) Journal. We are very excited that the journal has attracted papers from many countries. The variety of paper submissions has supported the international-level initiatives of the journal. Since the beginning of the year, a number of articles have been sent to us. Six articles are published in this issue, while others are still under the first or second phase of review and will follow in the subsequent issue.

In this issue, we present six articles on issues of technology and innovation development and policy at national-, regional-, and firm-level, written by scholars from Australia, Japan and Indonesia. The first article investigates the technological capability of the milk processing industry in Indonesia. The second article investigates mass production of innovation in the business model of start-up companies. The third article explores the diverse effects of four types of mobility on university entrepreneurship. The fourth article explores institutional transformations in local innovation systems used by the farmer community of Belu, East Nusa Tenggara, Indonesia. The fifth article analyzes the transition of bioplastic development in Indonesia, and the last article investigates the effectiveness of subsidies in technology adoption using the case study of reverse osmosis membrane technology in Mandangin Island, East Java, Indonesia. All articles have gone through editorial review by prominent experts.

I would like to thank the authors who have submitted articles to STIPM Journal for their trust, patience and timely revisions as well as for trusting Editor and Editorial Board. I encourage authors to submit their manuscripts. This scientific work is published widely on an open access policy.

My gratitude also goes to all members of the Editorial Board and reviewers who have contributed to this second issue, all of whom increase the quality of articles in this journal even more. We continue to welcome article submissions in the field of science, technology and innovation policy and management.

We wish you a 2017 Happy New Year!

Jakarta, December 2016

Editor-in-Chief 


\section{JOURNAL OF STI POLICY AND MANAGEMENT}

Volume 1, Number 2, December 2016

\section{LIST OF CONTENTS}

How Does the Milk Processing Industry in Indonesia Develop Their Technological Capability?

Budi Triyono, Chichi Shintia Laksani, Muhammad Zulhamdani, and Saut Siahaan $103-116$

Mass producing innovation: a case investigation on why accelerators might not be a paradox

Andrew Barnes

Exploring Diverse Effects of Four Types of Mobility on University Entrepreneurship

SatokoYasuda

Institutional Transformation of Local Innovation Systems in Farmer Community of Belu, East Nusa Tenggara

Febtri Wijayanti, Savitri Dyah, Rachmini Saparita, and Akmadi Abbas

Dynamics of Bioplastics Development in Indonesia

Qinan Maulana B. Soesanto, Dian Prihadyanti, Hartiningsih, and Trina Fizzanty.

Effectiveness of Subsidies in Technology Adoption: A Case Study Involving Reverse Osmosis (RO) Membrane Technology

Nur Laili, Rendi Febrianda, and Iin Surminah 163-170 



\title{
in STI POLICY AND MANAGEMENT \\ LIPI Journal homepage: http://www.stipmjournal.org
}

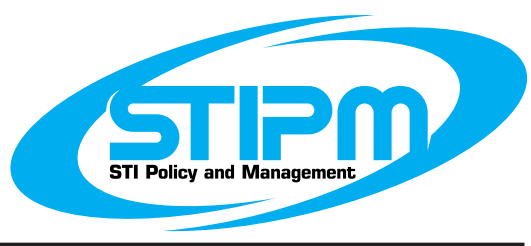

\section{Dynamics of Bioplastics Development in Indonesia}

\author{
Qinan Maulana B. Soesanto, Dian Prihadyanti, Hartiningsih, Trina Fizzanty \\ Center for Science and Technology Development Studies, Indonesian Institute of Sciences
}

\begin{tabular}{|c|c|}
\hline ARTICLE INFO & ABSTRACT \\
\hline $\begin{array}{l}\text { Article History: } \\
\text { Received : } 26 \text { January } 2016 \\
\text { Revised : } 27 \text { November } 2016 \\
\text { Accepted : } 2 \text { December } 2016 \\
\text { Available online : } 15 \text { December } 2016\end{array}$ & $\begin{array}{l}\text { Increases in consumption of conventional plastics have led to } \\
\text { environmental problems. Therefore, efforts are needed to overcome } \\
\text { it, with one possibility being the use of bioplastics. However, in } \\
\text { Indonesia, companies engaged in the bioplastics sector are still } \\
\text { rarely found. Without the readiness of the bioplastics industry in }\end{array}$ \\
\hline $\begin{array}{l}\text { Keywords: } \\
\text { Bioplastics } \\
\text { Conventional plastics } \\
\text { Degradable plastics } \\
\text { Transition process } \\
\text { Socio-technical system } \\
\text { Multi-level perspective }\end{array}$ & $\begin{array}{l}\text { problems, is an innovation that cannot be realized. Through an } \\
\text { approach based on a multi-level perspective framework, this paper } \\
\text { analyzes the dynamics of the bioplastics transition in Indonesia. } \\
\text { The results show that there exists the presence of pressure from } \\
\text { the socio-technical landscape to an underdeveloped niche. Socio- } \\
\text { technical regime actors may thus respond by modifying path } \\
\text { development of its innovation activities. In other words, Indonesia } \\
\text { has not yet experienced a transition in which bioplastics replace } \\
\text { conventional plastics. Instead, technology on the socio-technical } \\
\text { regime level changed through the development and advancement } \\
\text { of degradable plastics. }\end{array}$ \\
\hline
\end{tabular}

C2016 PAPPIPTEK-LIPI All rights reserved

\section{INTRODUCTION}

The high-volume use of conventional plastics made from crude oil has caused environmental problems in Indonesia due to its poor decomposable characteristics. In 2008, Indonesia had produced more than 4,000 metric tons of garbage per day in the form of plastic bags (Hardaning \& Adibroto, 2013). Studies show that in 2010, Indonesia was the second largest producer of plastic waste in the marine environment, totalling 0.48-1.29 million metric tons per year, following China, who produced 1.32-3.53 million metric tons of plastic waste per year (Jambeck et al.,

* Corresponding Author.

E-mail: Qinan.maulana@gmail.com
2015). If this plastic waste is not addressed immediately, the environmental problems will be worse due to the use of plastic bags. The problems urgently need to be overcomed by reducing the use of conventional plastic bags or substituting the use of these plastic bags with eco-friendly plastic bags made from bioplastics. One important action was conducted in early 2015 by the Indonesian government, which launched a policy where people have to pay for the use of plastic bags in supermarkets. However, this is only a short-term solution because it is not able to answer the high demand for plastic bags. Therefore, the development of bioplastics in Indonesia is necessary to answer the needs of the community 
for plastic bags and meet the requirements of the environment.

This paper will examine the dynamics of bioplastics development in Indonesia, particularly in efforts to replace conventional plastic bags that currently exist. Bioplastics and conventional plastics can be viewed as artifacts of technology, each having its own socio-technical system. This socio-technical system has aspects of technology, regulation, user habits, market, cultural significance, infrastructure, network maintenance and supply (Geels, 2005). In order to develop bioplastics in Indonesia, which is currently dominated by conventional plastics, there should be a transition which involves some or all aspects of the current socio-technical system of conventional plastics and of bioplastics. A transition, as referred to in this study, is a change from a conventional plastics socio-technical system to a bioplastics socio-technical system. Based on these concepts, this study uses a multi-level perspective (MLP) approach to analyze the dynamics of bioplastics transition in Indonesia.

Many studies on bioplastics have been conducted, but they are more technical, especially in terms of the use of methods and raw materials in the manufacture of bioplastics. One example, is a study conducted by Hartatik, Nuriyah and Iswarin (2014) relating to the effect of chitosan (from crustaceans) on the ability of degradation of bioplastic materials. Another study was conducted by Byun and Kim (2014), who researched the use of bioplastics for packaging and found that the bioplastic market is growing. Developments in bioplastics on the technical side is necessary as a first step in the transition process of conventional plastic to bioplastics. Nevertheless, these studies are not enough to understand the complete transition process. Bioplastics studies regarding social aspects, technology, and innovation in Indonesia are limited in number.

However, a related study conducted by Aminullah, Fizzanty, Indraprahasta and Asmara (2015) with a sectoral innovation systems approach shows that the convergence process of biology and chemistry disciplines is the basis for the development of bioplastics. Also, a socio-technical system approach using the MLP framework was conducted by Geels (2012), who studied the transition to a low-carbon transport sector. However, substantial studies on the transition of bioplastics or topics on bioplastics have not yet been conducted in Indonesia. Therefore, this study has a different approach compared to other studies in its use of the MLP framework as a guide to assess the dynamics of bioplastics development in Indonesia.

\section{ANALYTICAL FRAMEWORK}

The multi-level perspective is one of several analytical frameworks developed by researchers to conduct empirical studies on technology transition. The MLP approach has three analytical levels: the niche; the socio-technical regime; and the socio-technical landscape (Geels \& Schot, 2007; Nykvist \& Whitmarsh, 2008). Transitions are therefore the "outcomes of alignments between developments at multiple levels" (Geels \& Schot, 2007, p. 399).

The socio-technical regime is the space where dominant technologies exist. Geels (2002) proposes seven components of a socio-technical regime: technology, infrastructure, knowledge, markets and user practices, and cultural and symbolic meanings. Broadly speaking, the regime is the result of interactions between these seven components that together provide orientation and coordination so as to create stability and cohesion in the social technical system (Nykvist \& Whitmarsh, 2008). A socio-technical regime will stabilize itself because of "cognitive routines that blind engineers to developments outside their focus, regulations and standards, adaptation of lifestyles to technical systems, sunk investments in machines, infrastructures and competencies" (Geels \& Schot, 2007, p. 400). When receiving pressure from external forces, the regime will tend to adapt to maintain its position. This is because many actors in this regime are embedded in an established socio-technical network. This is also due to the investment which has been devoted to technology; therefore, competence and capabilities have grown, as well as the built-up infrastructure. Transition from one socio-technical regime to another is constrained 
by things such as vested interests, built-in inertia and current paradigms of thought and practice.

According to Geels and Schot (2007), the niche is the place where a new radical technology appears. The niche can serve as an incubation chamber that protects the new technology from the mainstream market. Technology in the niche can be developed by a small network consisting of actors dedicated to these new technologies. The actors are usually located outside of the regime. The niche not only covers new technology, but also includes institutions, markets, lifestyles and cultural elements, which all consist of networks, organizations and relevant actors (Nykvist \& Whitmarsh, 2008).

The socio-technical landscape is an environment beyond the direct influence of niche and regime actors, and it usually changes slowly (Geels \& Schot, 2007). Landscape covers changes in economic, ecological and cultural conditions. When the landscape changes, the regime may be under pressure, and usually adaptation to such changes will be slow because of the constraints built into the socio-technical regime. The regime may also be faster in providing solutions due to changes in the landscape (Nykvist \& Whitmarsh, 2008).

Geels and Schot (2007) proposed three transition processes. The first transition process occurs when the niche builds internal momentum through a learning process, increasing relative price ratio and the support of powerful groups. The second process occurs when changes to the landscape level creates pressure on the regime. The third process happens when instability in the regime, due to pressure from the landscape, creates a window of opportunity for radical innovation in the niche.

Simultaneous alignment of these processes will enable the breakthrough and entrance of the new technology into the mainstream market where they could then compete with the existing regime. Landscape change does not directly affect the regime and niche, but needs to be felt and translated by the actors. If the socio-technical landscape pressure occurs when a niche is not yet fully established, then the path of the transition to another socio-technical system will be different than if the niche has been established (Geels \& Schot, 2007).

Based on this analytical framework, as used in this study, bioplastics is categorized as a niche and conventional plastic is categorized as the regime. This is due to the domination of the utilization of conventional plastics in society and industry, especially for the purpose of wrapping bags.

The dynamics of bioplastics development in Indonesia is an analysis of the transition from conventional plastic to bioplastic, and how it could be driven by pressure from the sociotechnical landscape and through niches.

\section{METHODOLOGY}

This research paper used a qualitative method based on an MLP framework to analyze the dynamics of bioplastics development in Indonesia. Primary data was obtained through in-depth interviews with: academics/researchers in bioplastics development; two bioplastics companies; users of bioplastics; the government; and a nongovernmental organization (NGO). The primary data was supported by secondary data through a literature study. Data and information collected were categorized to the three MLP levels, based on the concept of a socio-technical system, which includes the niche, the socio-technical regime, and the socio-technical landscape. Based on the categorization, the condition of each level of the socio-technical system was described and their interconnectedness analyzed to understand the dynamics of bioplastics transtition in Indonesia.

\section{RESULTS}

The results section contains data on existing laws and regulations surrounding plastics, users of plastic bags, producers of plastic bags and research and development on bioplastics. Based on the interview results, there were two kinds of plastic bags in Indonesia, namely those made of conventional plastic and those made of eco-friendly plastic. Eco-friendly plastic might be in the form of: (i) degradable plastic that is conventional plastic with additive substances, such as oxo; (ii) bioplastic made from organic 
materials only (pure bioplastics), or made from plastic that is a mixture of the organic and conventional material.

The two types of bioplastic which were available in Indonesian markets were made from tapioca (cassava) and they were more expensive compared to conventional plastics or degradable plastics. For example, pure bioplastics were 2-3 times more expensive compared to conventional plastics, while mixed bioplastics was $10 \%$ more expensive, although it depended on the biomaterial therein. In this paper, degradable plastic was categorized as conventional plastic as it still used petroleum as its raw material, while the pure and mixed bioplastics were categorized as bioplastics.

\section{Laws and regulations related to plastics}

Based on data from the Ministry of Environment of Indonesia, in 2008, Indonesia produced approximately 5.4 million tons of plastic waste. Indonesia produced 15,000 tons plastic waste per day, 4,000 tons of which were in the form of plastic bags. Jakarta itself produced as much as 530 tonnes of plastic bags waste per day (Hardaning \& Adibroto, 2013). The presence of environmental problems due to the use of plastic bags pushed the government to issue regulations to address this environmental problem (see Table 1). One of these regulations aimed to reduce the use of plastic bags as well as increase the use of environmentally friendly plastic bags. In addition, through National Standardization Agency (BSN), the government set a national standard (SNI) for environmentally friendly plastic bags for shopping bags. One of the government regulation and standardization of environmentally friendly plastics was SNI (Indonesian National Standard) No. 7188/2011 about ecolabel criteria on plastic shopping bag product. To apply a disincentive for the use of conventional plastic, the government implemented a cost of Rp200 for consumers when using plastic bags provided by retail stores (Ministry of Environment Circulars, No. S1230/ PSLB3-PS/2016).

Local governments also generally launched initiatives as an effort to reduce the use of plastic bags, while also recommending the use of eco-friendly plastic bags. For example, the Jakarta government issued Regulation No. 3/2013 regarding waste management, which required modern stores to provide eco-friendly plastic bags. Besides Jakarta, the Bandung government also issued Regulation No. 17/2012 on the reduction of the use of plastic bags.

Table 1.

Laws and Regulations Relating to Plastic Waste in Indonesia

\begin{tabular}{|c|c|}
\hline Law/Regulation in Indonesia & Description \\
\hline Law No. $18 / 2008$ & $\begin{array}{l}\text { Regarding the obligation of business practices and community in reducing garbage by us- } \\
\text { ing degradable material, recycleable and or easily degraded by environment. Indonesia's } \\
\text { central and local government to conduct related activities, e.g. facilitating eco-friendly } \\
\text { technology implementation and eco-friendly product labelling. }\end{array}$ \\
\hline $\begin{array}{l}\text { Government Regulation No. } \\
81 / 2012\end{array}$ & $\begin{array}{l}\text { Management of household waste and similar waste, particularly in limiting landfill waste } \\
\text { by: 1) the use of product/packaging which can be recycled and easily biodegraded; } 2 \text { ) limi- } \\
\text { tation in plastic bag use; } 3 \text { ) avoiding the use of disposable products or packaging. }\end{array}$ \\
\hline $\begin{array}{l}\text { Ministry of Environment } \\
\text { Circulars, No. S1230/PSLB3- } \\
\text { PS/2016 }\end{array}$ & Pricing and mechanism of payment for plastic bags by consumers to reduce plastic waste. \\
\hline $\begin{array}{l}\text { DKI Jakarta Local Regulation } \\
\text { No. } 3 / 2013\end{array}$ & $\begin{array}{l}\text { Waste management, specifically limiting landfill waste by using recycleable products or } \\
\text { packaging and those easily biodegradable; limiting the use of conventional plastic bags and } \\
\text { avoiding the use of disposable products or packaging. This local regulation is the result of } \\
\text { government regulation. }\end{array}$ \\
\hline $\begin{array}{l}\text { Bandung Mayor Regulation } \\
\text { No. } 17 / 2012\end{array}$ & $\begin{array}{l}\text { Regulation regarding the reduction of plastic bags in Bandung, in the following stages: } 1 \text { ) } \\
\text { inventorizing the use of plastic bags; } 2 \text { ) arranging areas for reductions in the use of plastic } \\
\text { bag; 3) defining the local action plan on the reduction of plastic bags. This regulation also } \\
\text { states that every local producer of plastic bags must give efforts to produce eco-friendly } \\
\text { ones, while each business practitioner and plastic bag supplier must attempt to provide } \\
\text { eco-friendly plastic bags or other alternative bags. }\end{array}$ \\
\hline
\end{tabular}




\section{Users of plastic bags}

This section is based on the results of interviews with environmental officials, plastic bag producers, scientists, and plastic bag users (e.g. supermarkets). According to the above respondents, most supermarkets and minimarkets in Indonesia, particularly Jakarta, were already using degradable plastics, while there was limited use of bioplastics (Figure 1) because its price was still expensive. However, the use of degradable plastics had not yet penetrated traditional markets or grocery stores, which were still dominated by conventional plastics because of the higher price. Although the price difference between these plastics was relatively small, the slightly higher price was considered to be a burden on consumers.

Bioplastics consumers were usually companies that used bioplastics for product packaging. Examples of these companies were those which produced daily utensils, such as tissues, food and clothing, and product packaging distributions. Usually, these companies chose bioplastic products because their owners or the directors had their own vision regarding the importance of environmental issues. By using bioplastics in product packaging, some companies were trying to get eco-friendly labeling for their products, both domestically and abroad. The eco-friendly label became a marketing tool to attract consumers who are more environmentally aware.

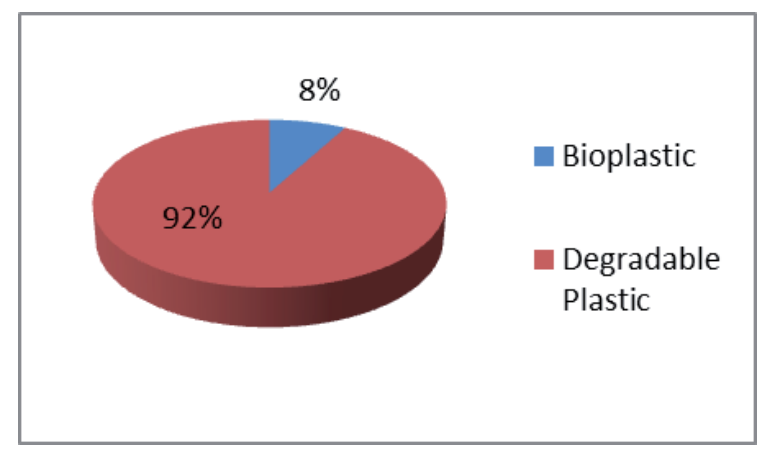

Source: Modified from Hardaning \& Adibroto (2013)

Figure 1. Composition of Eco-Friendly Plastic in Several Markets in Jakarta, 2012

In order to entice consumers, entities in both public and private sectors such as retail stores and other companies has widely campaigned the use of eco-friendly plastics. NGOs played an important role in promoting eco-friendly plastics, generally cooperating with the government or eco-friendly plastics producers. They did this through environmental activities, campaigns, education and awarding the retail or private parties who already used eco-friendly plastic as either the plastic shopping bags or in their product packaging. These activities were also beneficial for the company as a marketing strategy to introduce their products to communities. Campaigning and educational efforts were also carried out by supermarkets in the form of invitations to consumers to reduce the use of plastic bags by bringing their own shopping bags, or to pay for plastic bags they used from retail stores.

\section{Producers of plastic bags}

Based on interview results, prior to the release of government regulation relating to the use of eco-friendly plastic bags, plastics producers had already started to produce eco-friendly plastics, whether degradable plastics or bioplastics. Initiatives to produce eco-friendly plastic products generally emerged from the owner or director of the company itself. This was because of their awareness of the environmental impact, increased plastic waste, due to the use of conventional plastic, as well as in anticipation of business opportunities related to new potential markets.

Company X, for example, produced both conventional plastics and eco-friendly plastics, such as bioplastics and degradable plastics. The company has produced and marketed bioplastics since 2005. To meet the demand for eco-friendly plastic with a competitive price, the company also produced degradable plastic, beginning in 2008 .

The second example was Company $\mathrm{Y}$, which began to market eco-friendly plastic products such as bioplastics from 2012. In contrast to Company $\mathrm{X}$, Company $\mathrm{Y}$ originally had tried to produce degradable plastics, but the company finally decided to focus on the production of bioplastics despite being aware that its market share is relatively small. Respondents from Company $\mathrm{X}$ stated that both government regulations and Indonesia's National Standard (SNI) No. $7188 / 2011$ actually came after the eco-friendly plastic products appeared in the market. 
Table 2.

Condition of the Landscape, Niche, and Regime Surrounding Bioplastics

MLP level Condition
Landscape
-

Both bioplastics producers used cassava as the main raw material for their bioplastics. One of the companies even cooperated with local cassava farmers. The company committed to buy cassava from farmers at higher prices than the market price. The company also provided assistance to cassava farmers who supplied the company by providing training and by forming farmers' cooperatives for the welfare of the farmers.

Respondents from both bioplastics companies revealed that their bioplastics product were developed by investing for research, product development, and also marketing research, both domestically and abroad, without support from other parties. The companies' market shares were mostly abroad in countries that implemented strict rules regarding the use of plastic bags, such as countries in Europe and Africa. The domestic market for bioplastics was still relatively small because it was still dominated by conventional plastics, which currently has the advantage in terms of lower prices.

\section{Research and development on bioplastics}

Research concerned with bioplastics has been widely carried out by universities and governmental research and development (R\&D) institutions in Indonesia. The research body was mostly associated with a variety of raw materials as well as methods for producing bioplastics.

However, it had not effectively addressed development issues surrounding bioplastics because of weak research governance. Some of the problems included: (i) the absence of research focus (which would generally occured as a research roadmap) in answering future issues in bioplastics development; (ii) lack of intensity in cooperative relationships between $R \& D$ institutions and bioplastics companies, where current cooperation were limited to testing bioplastic products for certification purposes only.

Based on the descriptions from the previous section, the research findings could be categorized and summarized into the three functional levels based on the MLP framework. These levels were the socio-technical landscape, niche, and socio-technical regime; Table 2 shows these in the transition of bioplastics.

\section{DISCUSSION}

Environmental problems caused by the use of conventional plastic bags pushed the Indonesian government to issue related regulations. The regulations can be categorized as changes on the landscape level. Changes in the landscape suppresses conventional plastics regime; in other words, it is disruptive. Disruptive change can be defined as changes that develop gradually and has a high-intensity effect in one dimension (Geels \& Schot, 2007). The disruptive character of landscape changes is due to the nature of environmental problems, mainly related to plastic waste, which emerged slowly and gradually. The use of plastic packaging will continue to increase in line with increasing needs of the community and growing population in a city. By increasing 
the use of plastic bags, especially as they are difficult to decompose in the environment, problems related to the growing plastic waste emerged.

The use of plastic packaging probably did not cause environmental problems in the past, as the environmental carrying capacity was still high. However, with increasing needs and population, the environmental impact would start to be felt as these practices increased, thus changing existing environmental conditions. This change causes landscape changes, which does not happen suddenly but develops gradually and eventually has a considerably high impact. The change of landscape will suppress the existing regime that is, in this case, conventional plastics, so that the regime actors would need to respond. Changes in the landscape would not provide any immediate impact against the regime, but first need to be felt and translated by actors to draw out its influence (Geels \& Schot, 2007). In this study, it is perceived that one of the actions taken by a regime actor is the response to the government's issuance of regulations related to the use of plastic.

Pressure in the landscape causes actors in the regime, such as plastic companies as both producers and users, to invent technology development solutions to overcome the pressure of the landscape. This development resulted in the production of degradable plastic products. Degradable plastic is made of conventional plastic with additives such as oxo to ease the destruction of the plastic; in some specific products, this can be considered a biodegradable plastic. Many conventional plastics companies have started to use the technology for their products, including bioplastics companies.

Degradable plastics have an advantage in terms of prices that are much cheaper when compared to bioplastics and are competitive with conventional plastics. Thus the tendency is that degradable plastics substitutes the existing conventional plastics. This is proven by the dominant market share of degradable plastics in Indonesia compared with bioplastics. The market created an incremental change that could be determined as innovative.

In Indonesia, bioplastics are still at the level of niche. Changes in the landscape that suppress the conventional plastic regime has actually opened a gap for bioplastics to be able to replace the existing regime. However, the bioplastic niche is not ready to do that because of the economic aspect, and bioplastics are therefore unable to compete with conventional plastics and degradable plastics. This causes the structure of the economy and market of bioplastics to be underdeveloped. Bioplastics only have a small market share in Indonesia, though many of its users have certain preferences regarding factors such as the environmental aspect and economic aspect are not their top priority in using bioplastic.

Economic problems surrounding bioplastics are not supported with any answer readiness in

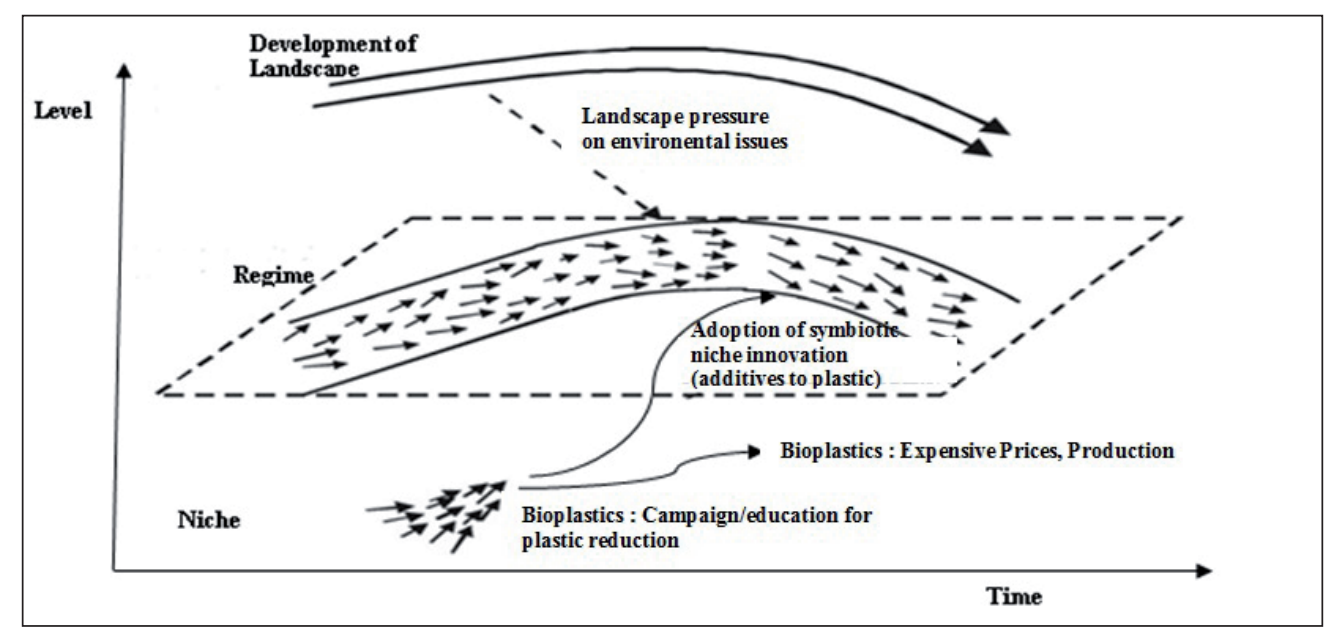

Source: Modified from Geels and Schot (2007)

Figure 2. Bioplastic Transition in Indonesia 
research due to the comparatively less intense relationship between scientists in research institutes and in the bioplastics industry. Therefore, the relationship between the two parties tends to be weak. This indicates weak social networking in the bioplastics niche, which has led to an unclear articulation of the cognitive structure among actors involved in bioplastics. This is marked by the absence of agreement on designs and specifications of bioplastics, or the so-called dominant design (Geels \& Schot, 2007). One example of the unclear dominant design is the unfocused development of bioplastics relating to the further advancement of bioplastic materials to the stage of commercialization. Answering this issue can also answer bioplastics' economic problems. Meanwhile, the bioplastic industry itself essentially has clear designs and specifications, for example the use tapioca/cassava as raw material in bioplastics.

The condition of bioplastics transition in Indonesia is shown in Figure 2. If there is pressure on the landscape when the niche is not yet sufficiently developed, the regime actors will respond by modifying the development path of innovation activity through incremental change. In other words, Indonesia has not experienced a transition in which biodegradable plastics replace conventional/degradable plastics. Instead of technology innovation in the socio-technical regime, the change that occurred was the development of plastic additives. This process is called a transformation path.

The concept of transformation path emphasizes the importance of actors outside the regime, because these actors translate pressure from the landscape and raise related issues regarding the negative impact of activities in the regime, whereas actors in the regime behave to reject the change. Pressure from NGOs or a social movement - actors outside the regime - would demand a solution for the pressure for change from the landscape. Researchers outside the regime provide an alternative path to the regime. In this case, bioplastics researchers have not yet found the dominant design, but they have demonstrated an alternative form of bioplastics research using certain materials. Companies outside the regime also develop alternative technologies - in this case, the bioplastics technology derived from cassava. Given these demonstrations by NGOs, researchers and companies outside the conventional plastic regime, the perception of actors within the regime will change. This causes a reorientation of innovation activity in the regime - in this case, the innovation of additives for plastic which has already been adopted by conventional plastic manufacturers.

At present, bioplastics in Indonesia is still at the niche level. The identified problem is the less competitive price when compared to conventional plastics or degradable plastics. One of the solutions to this problem is for research to find a new way to produce bioplastics with competitive prices. The first step must be to find a dominant design in bioplastics itself. One example of the importance of the dominant design is the advent of fossil-fueled cars. For example, the car that first appeared was a bio-fueled car; however, that design was defeated by fossil-fueled car design that eventually became the dominant design. Given this, the focus of the development of the car will be based on fossil fuel technologies, fuel efficiency, engine capacity, and so on. A similar process should be carried out in the case of bioplastics.

When the dominant design of bioplastics is assigned, the focus of research in solving the problem will become obvious. However, this does not mean that research beyond the dominant design will become unimportant and not carried out at all in practice. In discovering the dominant design, discussion is then needed to obtain a shared view among actors in the bioplastics niche.

\section{CONCLUSION}

Bioplastics in Indonesia has not yet replaced conventional and degradable plastic bags, particularly because the price is not competitive. The development of conventional plastics as a solution to address landscape pressure such as environmental problems, in turn leading to the shift to degradable plastics now widely used at the regime level. For future development, the bioplastics niche in Indonesia needs a strong 
network and a shared vision among bioplastic actors in determining its dominant design.

To that end, the main thing that is required is to form a bioplastics consortium which consists of researchers, governments, NGOs and industry, in which bioplastics actors can communicate and determine the dominant design, as well as define the roadmap for future development of bioplastics.

\section{ACKNOWLEDGEMENTS}

This paper was originally presented in Asialics Conference 2015 and has gone through more enrichment in the contents of this paper. This paper is also developed from the thematic research report at the Center for S\&T Development Studies, Indonesian Institute of Sciences on the transition model of bioplastics in Indonesia. Authors thank the Science and Technology Development Studies (PAPPIPTEK) - LIPI for funding this research and all supported parties who gave significant contributions.

\section{REFERENCES}

Aminullah, E., Fizzanty, T., Indraprahasta, G. S., \& Asmara, I. J. (2015). Technological convergence in Indonesian firms: Cases of biobased chemical product innovation. Asian Journal of Technology Innovation, 23, Issues sup1, 9-25. (http://dx.doi.org/10.1080/19761597.2015.10 11259)

Byun, Y., \& Kim, Y. T. (2014). Utilization of bioplastics for food packaging industry. In J. H. Han (Ed.), Innovations in food packaging (2nd ed., pp. 369-390). Elsevier. (http://dx.doi.org/10.1016/ B978-0-12-394601-0.00015-1)

Geels, F. W. (2002). Technological transitions as evolutionary reconfiguration processes: A multilevel perspective and a case-study. Research Policy, 31(2002), 1257-1274. (http://dx.doi. org/10.1016/S0048-7333(02)00062-8)
Geels, F. W. (2005). Technological transitions and system innovations: A co-evolutionary and socio-technical analysis, Cheltenham: Edward Elgar.

Geels, F. W., \& Schot, J. (2007). Typology of sociotechnical transition pathways. Research Policy, 36(2007), 399-417. (http://dx.doi. org/10.1016/j.respol.2007.01.003)

Geels, F.W. (2012). A Socio-technical analysis of low-carbon transitions: Introducing the multi-level perspective into transport studies. Journal of Transport Geography, 24(2012), 471-478. (http://dx.doi.org/10.1016/j.jtrangeo.2012.01.021)

Hardaning, P., \& Adibroto, T. (2013). Present status of environmentally degradable plastic in Indonesia. Presentation at $3^{\text {rd }}$ International Pastic Conference, 1-2 October 2013, Warsaw, Poland.

Hartatik, Y. D., Nuriyah, L., \& Iswarin. (2014). Pengaruh komposisi kitosan terhadap sifat mekanik dan biodegradable bioplastik. Student Physics Journal, 2(1).

Jambeck, J. R., Geyer, R., Wilcox, C., Siegler,T. R., Perryman, M., Andrady, A., Narayan, R., \& Law, K. L. (2015). Plastic waste inputs from land into the ocean. Research Report. 347(6223), Retrieved from Sciencemag.org. (http://dx.doi.org/10.1126/science.1260352)

Markard, J., Raven, R., \& Truffer, B. (2012). Sustainability transitions: An emerging field of research and its prospects. Research Policy, 41(2012), 955-967. (http://dx.doi. org/10.1016/j.respol.2012.02.013)

Nykvist, B., \& Whitmarsh, L. (2008). A multi level analysis of sustainable mobility transitions: Niche development in the UK and Sweden. Technological Forecasting \& Social Change, 75(2008), 1373-1387. (http://dx.doi. org/10.1016/j.techfore.2008.05.006) 